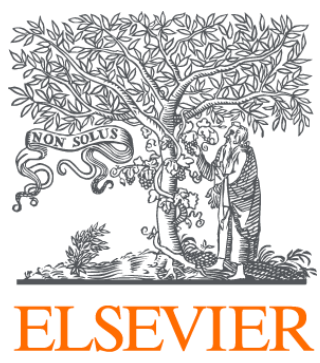

Since January 2020 Elsevier has created a COVID-19 resource centre with free information in English and Mandarin on the novel coronavirus COVID-

19. The COVID-19 resource centre is hosted on Elsevier Connect, the company's public news and information website.

Elsevier hereby grants permission to make all its COVID-19-related research that is available on the COVID-19 resource centre - including this research content - immediately available in PubMed Central and other publicly funded repositories, such as the WHO COVID database with rights for unrestricted research re-use and analyses in any form or by any means with acknowledgement of the original source. These permissions are granted for free by Elsevier for as long as the COVID-19 resource centre remains active. 
Letter to the Editor

\title{
A well-controlled Covid-19 cluster in a semi-closed adolescent psychiatry inpatient facility
}

\author{
Anne Tilmanne ${ }^{1,}{ }^{*}$, Gabrielle De Crombrugghe ${ }^{1}$, Mouna Al-Husni Al-Keilani ${ }^{2}$, \\ Guillaume Le Loc'h ${ }^{2}$, Véronique Delvenne ${ }^{2}$, Pierre R. Smeesters ${ }^{1,3,4,5}$ \\ ${ }^{1}$ Division of Pediatric Infectious Diseases and Infection Prevention and Control, Hôpital Universitaire des Enfants Reine Fabiola, Brussels, Belgium \\ ${ }^{2}$ Child Psychiatry Unit, Hôpital Universitaire des Enfants Reine Fabiola, Brussels, Belgium \\ ${ }^{3}$ Molecular Bacteriology Laboratory, Université libre de Bruxelles, Brussels, Belgium \\ ${ }^{4}$ Tropical Diseases Research Group, Murdoch Children's Research Institute, Melbourne, Australia \\ ${ }^{5}$ Department of Paediatrics, University of Melbourne, Melbourne, Australia
}

\section{A R T I C L E I N F O}

\section{Article history:}

Received 23 June 2020

Received in revised form

4 August 2020

Accepted 5 August 2020

Available online 14 August 2020

Editor: S.J. Cutler

To the editor.

Children are less frequently ill due to SARS-CoV-2 compared to adults [1]. However, the role of asymptomatic children and adolescent in disease transmission is still unknown and represents a major question in time of schools reopening.

We report a pauci-symptomatic SARS-CoV-2 positive 14 -yearsold boy in a semi-closed child psychiatry inpatient facility. This unit welcomes 15 young people aged from 8 to 15 years old, in crisis for an average period of 6 weeks to 3 months. They are admitted for different purposes: suicidal attempt, depression, anorexia, behavior disorders, psychotic disorders.

On Day 0, the patient complained of a runny nose with no other symptoms. On day 1 , SARS-CoV-2 antigenic test returned positive on a naso-pharyngeal swab a week after a contact with a SARSCoV-2 positive and hospitalised parent. The patient could neither be sent home nor transferred to a paediatric ward for reason linked to his symptomatology. After team discussions, we decided to keep the patient in our facility and enforce strict infection prevention measures to protect both inpatients and health-care workers (Table 1). From day 8 to day 43, a total of 14 patients were tested per protocol twice a week for SARS-CoV-2 in their nasopharynx. All remained asymptomatic. The inpatient length of stay ranged from 1-5 weeks. All patients stayed in the facility all the time once admitted. The index case was tested twice a week. He tested positive from day 1 to his discharge on day 13 and an asymptomatic 14-years-old girl was also positive from day 8 to day 29. Given the 4-12 days incubation period, we do not know whether the transmission to the secondary case occurred before or after the implementation of infection control measures. None of the 12 other patients were ever positive during the 5 weeks follow-up and none of the health-care workers declared any symptom.

Some data suggest children are less susceptible to acquire, and eventually to transmit, the virus than adults. A study in China including 105 cases and 392 household contacts showed $20.5 \%$ secondary transmission in adults (60/292) compared to $4.0 \%$ in children $(4 / 100)$ [2]. A symptomatic SARS-CoV-2 positive nine-years-old child did not infect any of his 112 school contacts in 3 schools and ski class despite transmission of other viruses [3] and children are the first to develop SARS-CoV-2 symptoms in only $8 \%(3 / 39)$ of family clusters [4]. Other studies reported non-differential attack rates in all age categories (around 6-7\%) in the follow-up of 244 patients and 1286 close contacts [5].

Managing SARS-CoV-2 paediatric risk and health-care workers protection in an objective way is complicated. We described a successful multidisciplinary management of two positive cases in a semi-closed child psychiatry inpatient facility. No further contaminations occurred after implementation of appropriate infection control measures still allowing social life for children.

\footnotetext{
* Corresponding author: Anne Tilmanne, Hôpital Universitaire Des Enfants Reine Fabiola, Avenue JJ Crocq 15, 1020 , Brussels, Belgium. +32247733.60.

E-mail address: Anne.tilmanne@huderf.be (A. Tilmanne).
} 
Table 1

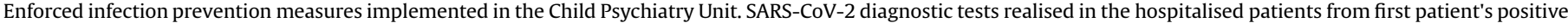
test result to 10 days after last positive test

\begin{tabular}{|c|c|c|c|c|c|c|c|c|c|c|c|c|c|}
\hline \multicolumn{3}{|c|}{ Unit description } & \multicolumn{7}{|c|}{ Infection control measures in place since day 1} & \multicolumn{4}{|c|}{ Contacts still allowed after day 1} \\
\hline \multicolumn{3}{|c|}{$\begin{array}{l}\text { - Semi-closed inpatient } \\
\text { psychiatry unit with } 15 \\
\text { patients } \\
\text { - } 10 \text { bedrooms } 5 \\
\text { Individual and } 5 \text { double } \\
\text { bedrooms) } \\
\text { - } 19 \text { members of staff with } \\
8 \text { staff present in the unit } \\
\text { during the day and } 2 \\
\text { during the night } \\
\text { - Common living, dining } \\
\text { and play area } \\
\text { - } 4 \text { toilets and } 3 \text { bathrooms }\end{array}$} & \multicolumn{7}{|c|}{$\begin{array}{l}\text { - Positive patient bedroom was individual and considered as a contamined } \\
\text { space } \\
\text { - Health-care workers had to wear a protection gown and gloves to go into that } \\
\text { bedroom. } \\
\text { - Access to the bedroom was not granted to other children. } \\
\text { - Infected patient had to wear a surgical mask at any moment outside the } \\
\text { bedroom. } \\
\text { - Infected patient had to disinfect the hands with hydroalcoholic solution } \\
\text { before leaving the bedroom and at each time he touched his mask or his face. } \\
\text { - Infected patient had an own bathroom and toilet which could not be used by } \\
\text { other patients } \\
\text { - Social distancing ( } 1 \cdot 5 \text { meter) was required between all inpatients and with } \\
\text { the health-care workers } \\
\text { - The infected patient had non reusable cutlery and plate, which were thrown } \\
\text { away after use in a contaminated garbage can. } \\
\text { - Group activities were adapted to be preferably undertaken outside, with no } \\
\text { shared materials } \\
\text { - Each patient had a personal locker with his craft material, pencils } \\
\text { - Cards play, books exchanges were not allowed but board games through } \\
\text { connected tablets were promoted } \\
\text { - Home visits were cancelled }\end{array}$} & \multicolumn{4}{|c|}{$\begin{array}{l}\text { - Meals were taken together, with the positive } \\
\text { patient, in the kitchen with } 2 \text { meters between } \\
\text { each other's. } \\
\text { - Social activities were maintained in groups } \\
\text { with all patients } \\
\text { - The parents, one at a time, were allowed to } \\
\text { visit their child for a few hours each day } \\
\text { with surgical mask and hand hygiene }\end{array}$} \\
\hline & Age & Day 1 & Day 8 & Day 12 & Day 15 & Day 19 & Day 22 & Day 26 & Day 29 & Day 33 & Day 36 & Day 40 & Day 43 \\
\hline 1 & $13 \cdot 8$ & $\mathrm{Ag}$ & PCR & PCR & - & - & - & - & - & - & - & - & - \\
\hline 2 & $13 \cdot 8$ & - & neg & neg & neg & - & - & - & - & - & - & - & - \\
\hline 3 & $12 \cdot 8$ & - & neg & neg & neg & neg & neg & neg & neg & neg & neg & neg & neg \\
\hline 4 & $14 \cdot 5$ & - & $\mathrm{Ag}$ & PCR & PCR & PCR & PCR & neg & PCR & neg & neg & neg & neg \\
\hline 5 & $14 \cdot 8$ & - & neg & neg & neg & neg & neg & - & - & - & - & - & - \\
\hline 6 & $11 \cdot 3$ & - & neg & neg & neg & neg & neg & neg & neg & neg & neg & neg & neg \\
\hline 7 & $10 \cdot 8$ & - & - & neg & neg & neg & neg & neg & neg & neg & neg & neg & neg \\
\hline 8 & $11 \cdot 4$ & - & - & - & - & - & neg & neg & neg & neg & neg & neg & neg \\
\hline 9 & $13 \cdot 8$ & - & - & - & - & neg & neg & neg & neg & - & - & - & neg \\
\hline 10 & $14 \cdot 3$ & - & - & - & - & neg & neg & neg & neg & neg & neg & neg & neg \\
\hline 11 & $13 \cdot 5$ & - & - & - & - & - & - & - & - & neg & neg & neg & neg \\
\hline 12 & $13 \cdot 5$ & - & - & - & - & - & - & - & - & neg & neg & neg & neg \\
\hline 13 & $9 \cdot 9$ & - & - & - & - & - & - & - & - & neg & neg & neg & neg \\
\hline 14 & $11 \cdot 3$ & - & - & - & - & - & - & - & - & - & - & neg & neg \\
\hline
\end{tabular}

$\mathrm{Ag}=$ SARS-CoV-2 antigenic test positive; $\mathrm{PCR}=\mathrm{SARS}-\mathrm{CoV}-2$ PCR test positive; neg = SARS-CoV-2 PCR test negative.

\section{Conflict of interest}

Authors have nothing to disclose.

\section{Funding}

No external funding was received for this study.

\section{Authors' contributions}

AT and PS were in charge of the infection prevention policies. MA, GL and VD were in charge of the child psychiatric unit. GD helped in the measure's implementation. AT and PR wrote the letter. All authors provided critical conceptual input and critically revised the letter.

\section{References}

[1] CDC COVID-19 Response Team. Coronavirus disease 2019 in children - United States, february 12-april 2, 2020. MMWR Morb Mortal Wkly Rep 2020;69: 422-6. https://doi.org/10.15585/mmwr.mm6914e4.

[2] Li W, Zhang B, Lu J, Liu S, Chang Z, Cao P, et al. The characteristics of household transmission of COVID-19. Clin Infect Dis 2020. https://doi.org/10.1093/cid/ ciaa450.

[3] Danis K, Epaulard O, Bénet T, Gaymard A, Campoy S, Bothelo-Nevers E, et al. Cluster of coronavirus disease 2019 (Covid-19) in the French alps, 2020. Clin Infect Dis 2020. https://doi.org/10.1093/cid/ciaa424.

[4] Posfay-Barbe KM, Wagner N, Gauthey M, Moussaoui D, Loevy N, Diana A, et al. COVID-19 in children and the dynamics of infection in families. Pediatrics 2020 https://doi.org/10.1542/peds.2020-1576.

[5] Bi Q, Wu Y, Mei S, Ye C, Zou X, Zhang Z, et al. Epidemiology and transmission of COVID-19 in 391 cases and 1286 of their close contacts in Shenzhen, China: a retrospective cohort study. Lancet Infect Dis 2020. https://doi.org/10.1016 S1473-3099(20)30287-5. 